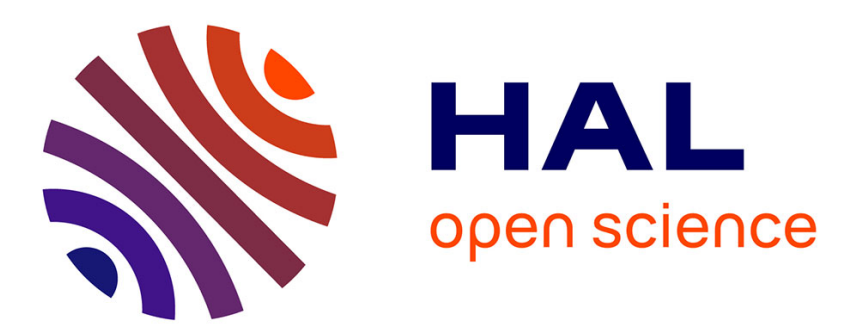

\title{
Analysis of Sugar Component of a Hot Water Extract from Arabidopsis thaliana Pollen Tubes Using GC-EI-MS
}

\author{
Marie Dumont, Arnaud Lehner, Corinne Loutelier-Bourhis, Jean-Claude \\ Mollet, Patrice P. Lerouge
}

\section{To cite this version:}

Marie Dumont, Arnaud Lehner, Corinne Loutelier-Bourhis, Jean-Claude Mollet, Patrice P. Lerouge. Analysis of Sugar Component of a Hot Water Extract from Arabidopsis thaliana Pollen Tubes Using GC-EI-MS. Bio-protocol , 2015, 5 (12), pp.e1503. 10.21769/BioProtoc.1503 . hal-01838553

\section{HAL Id: hal-01838553}

\section{https://hal-normandie-univ.archives-ouvertes.fr/hal-01838553}

Submitted on 5 Sep 2019

HAL is a multi-disciplinary open access archive for the deposit and dissemination of scientific research documents, whether they are published or not. The documents may come from teaching and research institutions in France or abroad, or from public or private research centers.
L'archive ouverte pluridisciplinaire HAL, est destinée au dépôt et à la diffusion de documents scientifiques de niveau recherche, publiés ou non, émanant des établissements d'enseignement et de recherche français ou étrangers, des laboratoires publics ou privés. 


\section{Analysis of Sugar Component of a Hot Water Extract from Arabidopsis thaliana Pollen Tubes Using GC-EI-MS}

Marie Dumont ${ }^{1}$, Arnaud Lehner ${ }^{1}$, Corinne Loutelier-Bourhis ${ }^{2}$, Jean-Claude Mollet ${ }^{1}$ and Patrice Lerouge $^{1 *}$

${ }^{1}$ Laboratoire de Glycobiologie et Matrice Extracellulaire Végétale (Glyco-MEV) EA4358, Normandy University, University of Rouen, Institut de Recherche et d'Innovation Biomédicale, Mont-Saint-Aignan, France; ${ }^{2}$ Normandie Université, COBRA, Université de Rouen, INSA de Rouen, CNRS, IRCOF, Mont-Saint-Aignan, France

*For correspondence: patrice.lerouge@univ-rouen.fr

[Abstract] Extraction with hot water is the oldest and simplest method used to recover pectin from an alcohol insoluble residue extract, although this method has not been widely used for the cell wall analysis of pollen tube, a model used to study cell wall. This protocol described this method applied for pectin extraction from $6 \mathrm{~h}$-old Arabidopsis pollen tubes followed by a sugar composition analysis by gas chromatography mass spectrometry.

\section{Materials and Reagents}

1. Arabidopsis day-0 flowers according to Boavida and McCormick (2007)

2. Absolute ethanol (EtOH) for analysis (Merck Millipore, catalog number: 107017)

3. Trifluoroacetic acid 12.93N (TFA) (Sigma-Aldrich, catalog number: T62200)

4. Myo-inositol $2 \mathrm{mM}$ (Sigma-Aldrich, catalog number: 15125)

5. Methanolic- $\mathrm{HCl} 3 \mathrm{~N}$ (Sigma-Aldrich, catalog number: 33051 Supelco)

6. Methanol (Thermo Fisher Scientific, catalog number: 10010280)

7. Silylation reagent (HMDS:TMCS:Pyridine, 3:1:9 Sylon ${ }^{\mathrm{TM}}$ HTP) (Sigma-Aldrich, catalog number: 33038 Supelco)

8. Cyclohexane (Acros Organics, catalog number: 279590010)

9. Monosaccharides standards

Arabinose (Sigma-Aldrich, catalog number: A3256)

Fucose (Sigma-Aldrich, catalog number: F8150)

Galactose (Sigma-Aldrich, catalog number: G0750)

Galacturonic acid (Sigma-Aldrich, catalog number: 857289)

Glucose (Merck Millipore, catalog number: 8337.0250)

Glucuronic acid (Sigma-Aldrich, catalog number: G8645)

Mannose (Sigma-Aldrich, catalog number: M4625)

Rhamnose (Sigma-Aldrich, catalog number: R3875)

Xylose (Sigma-Aldrich, catalog number: X2126)

10. Arabidopsis pollen germination medium (see Recipes) 
11. Trifluoroacetic acid (2 N) (see Recipes)

\section{Equipment}

1. Inverted microscope Olympus CK2

2. Centrifuge Allegra ${ }^{\circledR} \mathrm{X}-15 \mathrm{R}$ Beckmann Coulter

3. Hot-water bath $\left(70^{\circ} \mathrm{C}\right.$ and $\left.90^{\circ} \mathrm{C}\right)$

4. 40-ml glass potter homogenizer

5. Freeze-dryer

6. Incubator $\left(22^{\circ} \mathrm{C}, 80^{\circ} \mathrm{C}\right.$ and $\left.110^{\circ} \mathrm{C}\right)$

7. Sample concentrator under air flow (Techne, catalog number: FSC400D)

8. GC-El-MS instrument is composed of a Zebron Z5-MSi $(30 \mathrm{~m}, 0.25 \mathrm{~mm}$ id, $0.25 \mu \mathrm{m}$ film thickness, Phenomenex) capillary column for chromatographic separations, a Hewlett-Packard 6890 series gas chromatograph coupled to an Autospec mass spectrometer of EBE geometry (Micromass, Manchester, UK) equipped with a Opus 3.1 data system

9. $1.5 \mathrm{ml}$ Eppendorf tube

10. Vortex

11. Pair of tweezers

12. 50 -ml Falcon

13. Microliter syringe ( $10 \mu \mathrm{l}$, Hamilton)

\section{Procedure}

A. In vitro Arabidopsis pollen tubes growth and fixation

The protocol described below is similar to the one available at Wang and Jiang (2014) with several differences.

1. Grow in vitro Arabidopsis pollen according to the method described by Boavida and McCormick (2007).

a. Harvest 40 freshly open Arabidopsis thaliana flowers (morning is the best).

b. Submerge in $1 \mathrm{ml}$ of pollen germination medium in a $1.5 \mathrm{ml}$ Eppendorf tube.

c. Shake the tube vigorously manually and using a vortex for $5 \mathrm{~min}$ to release the pollen grains from the anthers.

d. Check the pollen density with an inverted microscope.

e. Remove all the flower debris with a pair of tweezers.

f. Spin-down the pollen suspension at 3,200 $\times \mathrm{g}$ for $7 \mathrm{~min}$ (a yellowish pellet should be visible).

g. Remove the supernatant.

h. Add $250 \mu$ l of pollen germination medium and resuspend the pellet.

i. Place the tube horizontally in the incubator at $22^{\circ} \mathrm{C}$ in the dark for $6 \mathrm{~h}$. 


\section{bĭo-protocol}

j. After $6 \mathrm{~h}$, check for pollen germination and pollen tube growth with the inverted microscope (Figure 1).

2. Fix the pollen culture by adding $750 \mu \mathrm{l}$ absolute $\mathrm{EtOH}$ (final concentration $75 \% \mathrm{EtOH}$ ) and keep at $4{ }^{\circ} \mathrm{C}$ (no longer than one month).

Note: Around 90 pollen cultures (3,600 flowers) are needed for the detection of minor sugars such as the Kdo (2-keto-3-deoxy-D-manno-octulosonic acid), one of the constituents of rhamnogalacturonan-II (RG-II). For other major cell wall components, pollen tubes from 400 flowers are generally sufficient.

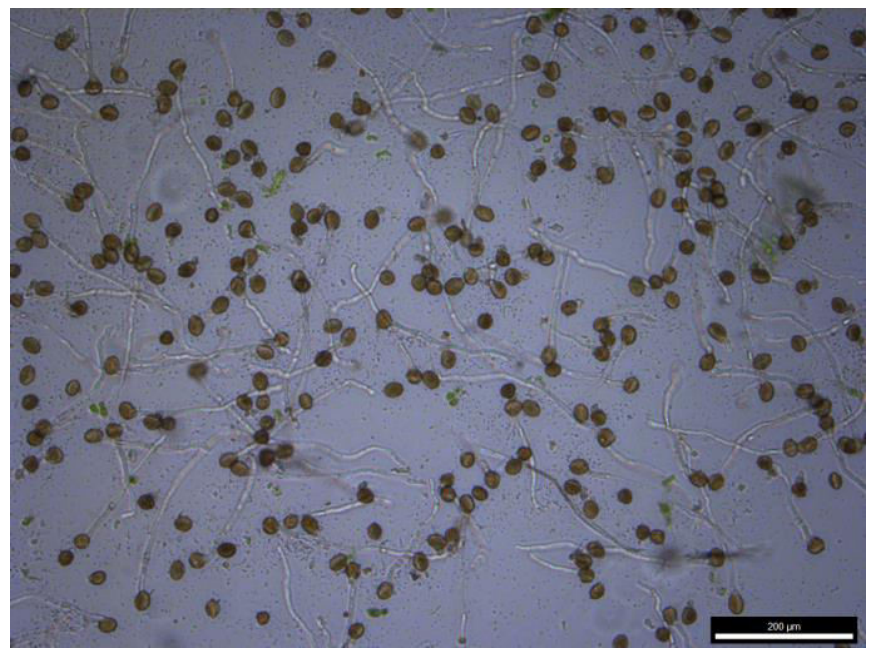

Figure 1. 6 h-old Arabidopsis pollen tubes. Note that the pollen grain density is important to obtain a good germination rate.

B. Pectin extraction and analysis

1. Hot water pectin extraction:

a. Pool all the pollen cultures in a 50-ml Falcon ${ }^{\circledR}$ tube and centrifuge at $4,700 \times g$ for $5 \mathrm{~min}$. Repeat the centrifugation step if the total volume of the pollen cultures exceeds $45 \mathrm{ml}$.

b. Discard the supernatant and wash with $15 \mathrm{~mL} \mathrm{EtOH} 70 \%$ to remove salt and sucrose from the germination medium.

c. Incubate in hot-water bath at $70^{\circ} \mathrm{C}$ for $15 \mathrm{~min}$.

d. Grind the material manually with a $40-\mathrm{ml}$ glass potter homogenizer until no debris are visible.

e. Centrifuge at 4,700 $\times g$ for $5 \mathrm{~min}$ and discard the supernatant.

f. Allow the pellet to dry until no supernatant is visible (it might take no more than $2 \mathrm{~h}$ using a stream of dry air).

g. Resuspend the pellet in $5 \mathrm{ml}$ distilled water.

h. Incubate in a hot-water bath at $90^{\circ} \mathrm{C}$ for $1 \mathrm{~h}$.

i. Centrifuge at $4,700 \times \mathrm{g}$ for $5 \mathrm{~min}$.

j. Freeze-dry the supernatant. No liquid must be visible (it might take one day). 
2. Sample preparation for gas chromatography analysis:

Note: Glassware tubes are preferentially used for the sample preparation. A standard sample containing the most common cell wall monosaccharides (Ara, Fuc, Gal, GalUA, Glc, GlcUA, Man, Rha, Xyl) is prepared at the same time without the TFA hydrolysis step.

a. Hydrolyze the extract with $250 \mu \mathrm{ITFA} 2 \mathrm{~N}$ for $2 \mathrm{~h}$ at $110^{\circ} \mathrm{C}$.

b. Add $50 \mu \mathrm{l}$ of myo-inositol $2 \mathrm{mM}$ in the sample. Myo-inositol is used as an internal standard.

c. Perform a methanolysis for $16 \mathrm{~h}$ at $80^{\circ} \mathrm{C}$ using $250 \mu$ of dried $1 \mathrm{M}$ methanolic- $\mathrm{HCl}$ (dilute the $3 \mathrm{M}$ stock solution with methanol).

d. Wash the sample twice using $500 \mu \mathrm{l}$ methanol.

e. Convert the methyl glycosides into their trimethylsilyl derivatives at $110^{\circ} \mathrm{C}$ for 20 min with $200 \mu \mathrm{l}$ of the silylation reagent (HMDS: TMCS: Pyridine, 3:1:9, Supelco).

f. Wash twice the sample using $500 \mu$ l cyclohexane.

Note: Air dry the sample using a stream of dry air with a sample concentrator between each step (a nitrogen flow can be used as well). Add $1 \mathrm{ml}$ cyclohexane and vortex the tube.

3. Monosaccharides analysis:

a. Inject $0.5 \mu \mathrm{l}$ of the sample in the GC-El-MS instrument, using a $10 \mu \mathrm{l}$ syringe, in splitless mode. Helium is the carrier gas and the flow-rate is $0.8 \mathrm{ml} / \mathrm{min}$.

b. Start the temperature programming at $120{ }^{\circ} \mathrm{C}$ for $2 \mathrm{~min}$, ramp to $160{ }^{\circ} \mathrm{C}$ at $10^{\circ} \mathrm{C} / \mathrm{min}$, then to $220^{\circ} \mathrm{C}$ at $1.5^{\circ} \mathrm{C} / \mathrm{min}$ and finally ramp to $280^{\circ} \mathrm{C}$ at $15^{\circ} \mathrm{C} / \mathrm{min}$ (maintain at $270{ }^{\circ} \mathrm{C}$ for $1 \mathrm{~min}$ ). The temperatures of the injector, the interface and the lines are $250^{\circ} \mathrm{C}$. Record the El mass spectra using an electron energy of 70 $\mathrm{eV}$, an acceleration voltage of $8 \mathrm{kV}$ and a resolving power of 1,000 . The trap current of $200 \mu \mathrm{A}$ and the magnet scan rate is $1 \mathrm{~s} /$ decade over a $\mathrm{m} / \mathrm{z}$ range 600-38. The temperature of ion source is $250^{\circ} \mathrm{C}$.

c. The data are processed with the software STAR Workstation Varian 5.52. First of all, it is important to check that peak and peak areas $(A)$ are assigned correctly for each spectrum by comparing with the standard sample before proceeding. The response factor $\left(R_{f}\right)$ for each monosaccharide has been determined previously by calibration of the instrument for each standard sugar. Peak area is integrated on the total chromatogram for each sugar and for the internal standard (inositol). The amount of each sugar is calculated by the formula:

Sugar concentration $(x)=\frac{\mid(\text { inositol concentration peak area }(x)) \text { inositol peak } \mid}{(R f(x))}$

Figure 2 gives an overview of the complete protocol. 


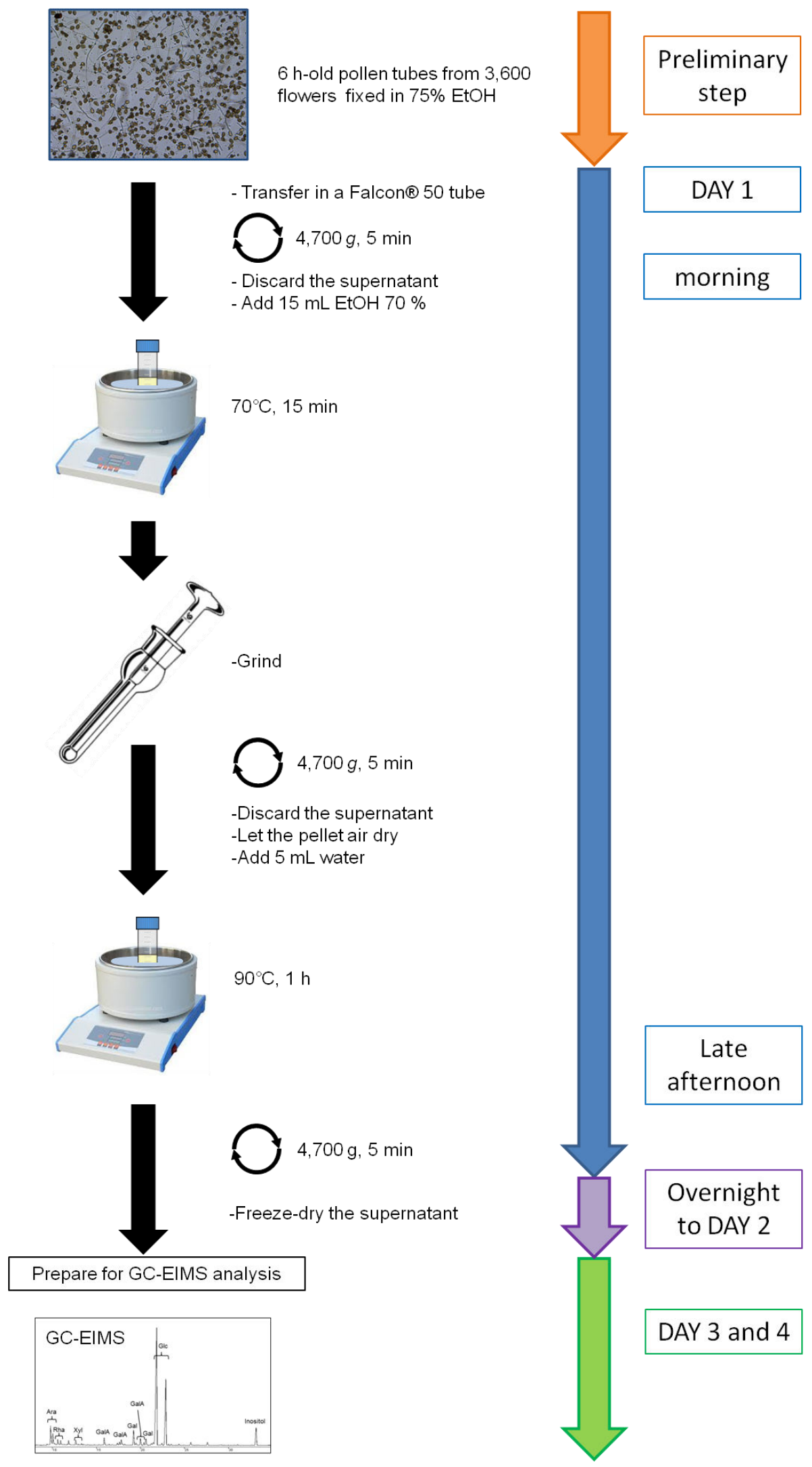

Figure 2. Schematic representation of the protocol for sugar composition of a hot water extract from Arabidopsis thaliana pollen tubes 


\section{$\underline{\text { Recipes }}$}

1. Arabidopsis thaliana pollen germination medium

$5 \mathrm{mM} \mathrm{CaCl}_{2}$

$0.01 \% \mathrm{H}_{3} \mathrm{BO}_{3}$

$1 \mathrm{mM} \mathrm{MgSO}_{4}$

$5 \mathrm{mM} \mathrm{KCl}$

$10 \%(w / v)$ sucrose

$\mathrm{pH} 7.5$

2. Trifluoroacetic acid $(2 \mathrm{~N})$

0.15 volume of Trifluoroacetic acid $12.93 \mathrm{~N}$

0.85 volume of fresh distilled water

Note: Use glassware.

\section{Acknowledgments}

This protocol was initially described in Dumont et al. (2014). This work was supported by the University of Rouen, the region Haute-Normandie, and the "Trans Channel Wallnet" project that has been selected by the INTERREG IVA program France (Channel) England European cross-border cooperation programme, which is co-financed by the ERDF. The authors also thank the Labex SynOrg (ANR-11-LABX-0029, CRUNCh network, and the European Regional Development Fund (ERDF 31708).

\section{References}

1. Boavida, L. C. and McCormick, S. (2007). TECHNICAL ADVANCE: Temperature as a determinant factor for increased and reproducible in vitro pollen germination in Arabidopsis thaliana. Plant J 52(3): 570-582.

2. Dumont, M., Lehner, A., Bouton, S., Kiefer-Meyer, M. C., Voxeur, A., Pelloux, J., Lerouge, P. and Mollet, J. C. (2014). The cell wall pectic polymer rhamnogalacturonan-II is required for proper pollen tube elongation: implications of a putative sialyltransferase-like protein. Ann Bot 114(6): 1177-1188.

3. Wang, H. and Jiang, L. (2014). Immunofluorescence labeling of pollen tubes. Bio-protocol 4(10): e1131. 